INTER NATIONAL MONETARY FUND
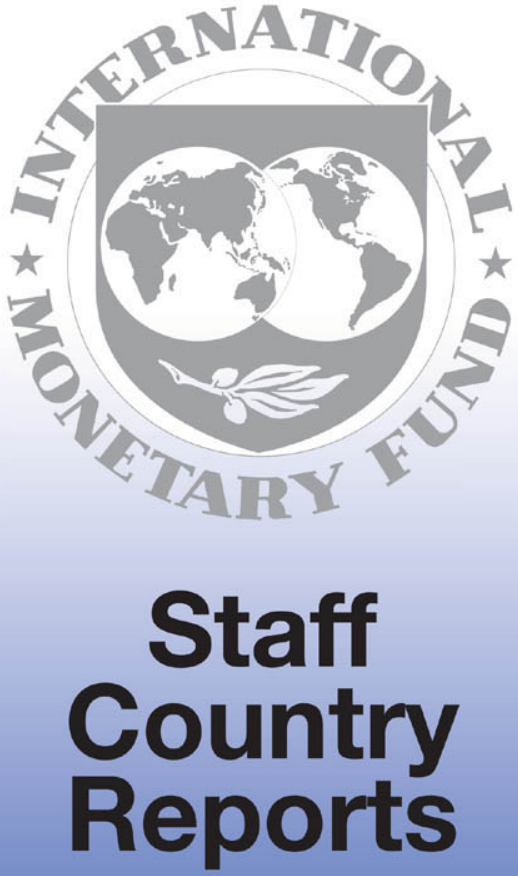


\section{Slovak Republic: Report on the Observance of Standards and Codes-Fiscal Transparency Module-Update}

This update to the Report on the Observance of Standards and Codes on Fiscal Transparency Module for the Slovak Republic was prepared by a staff team of the International Monetary Fund as background documentation for the periodic consultation with the member country. It is based on the information available at the time it was completed on July 16,2003 . The views expressed in this document are those of the staff team and do not necessarily reflect the views of the government of the Slovak Republic or the Executive Board of the IMF.

The policy of publication of staff reports and other documents by the IMF allows for the deletion of market-sensitive information.

To assist the IMF in evaluating the publication policy, reader comments are invited and may be sent by e-mail to publicationpolicy@imf.org.

Copies of this report are available to the public from

International Monetary Fund - Publication Services

700 19th Street, N.W. • Washington, D.C. 20431

Telephone: (202) 6237430 • Telefax: (202) 6237201

E-mail: publications@imf.org • Internet: http://www.imf.org

\section{International Monetary Fund \\ Washington, D.C.}




\section{REPORT ON THE OBSERVANCE OF STANDARDS AND CODES Slovak RePublic-Fiscal TransParency Module: AN Update JULY 2003}

\section{INTRODUCTION}

1. The original fiscal Report on the Observance of Standards and Codes (ROSC) was issued in July 2002. ${ }^{1}$ During the 2003 Article IV consultation, the IMF staff reviewed developments in the areas pertaining to Slovakia's observance of the fiscal transparency practices assessed in 2002, with a view to updating, where relevant, changes in current practices, or describing the implementation of the earlier ROSC's recommendations. This note reports on developments in fiscal transparency in Slovakia since the original ROSC. For a full description of institutions and practices, and Fund staff recommendations, this update should be read in conjunction with the original report.

2. Last year's ROSC acknowledged the progress made by Slovakia in recent years to improve fiscal management and transparency, and concluded that Slovakia met several of the requirements of the Code of Good Practices on Fiscal Transparency. At the same time, the report also identified the following areas where progress would be needed to meet all the requirements of the code and to move toward best practices: (i) a better definition of the coverage of general government and of the relations between the central and general government and the rest of the public sector; (ii) better accounting, classification, and reporting of fiscal operations; (iii) further improvements in the quality of fiscal data and the transparency of budget management; and (iv) more careful consideration of long-term policy commitments and fiscal risks.

\section{Description of Progress}

\section{A. Clarity of Roles and Responsibilities}

3. The original ROSC suggested that the coverage of fiscal operations be strengthened by: ensuring the effective compliance of the definitions of central and general governments with the European System of Accounts, 1995 (ESA95); reviewing the coverage of nonprofit organizations performing government functions; establishing a transparent formula for key tax sharing agreements between the central government and the regions and municipalities; clarifying the mandate of the National Property Fund (NPF) as to the management of privatized enterprises; making the regulatory framework clearer and more open; and including the list of government's equity holdings in the state final account, and recording them in its balance sheets at market values.

${ }^{1}$ The original report, entitled Slovak Republic-Report on the Observance of Standards and Codes-Fiscal Transparency Module (SM/02/219, July 15, 2002), is available on the IMF website http://www.imf.org/external/np/rosc. 
4. Consistent with these recommendations, the following actions were taken in the past year:

- The National Statistics Office, which is responsible for the definitions of central and general government, has ensured the effective compliance of such definitions with ESA95. The state final accounts for 2002 and the budget for 2003 have applied these coverage definitions entirely.

- Regarding the coverage of non-profit organizations, the draft 2004 budget includes public schools and universities as part of general government. For other non-profit organizations not part of general government (e.g., some hospitals recently transferred to those organizations), subsidies are recorded explicitly in the state budget.

- In the context of the 2004 budget, the authorities are dealing with the debt situation of the railways in a comprehensive and more transparent manner. The government has agreed to assume a substantial share of the railways' (state guaranteed) outstanding debt stock, in exchange for clearing the government's debt obligations to the railways (owing to subsidies to tickets for the military, students, and pensioners). In addition, a clear contractual agreement has been made between the railways and the transport ministry, which links the social service obligations of the railways directly to the transportation subsidy that is included in the budget.

- The regulatory framework was made clearer and more open by, effective January 2003, having the Regulatory Office for Network Industries take over the price administration of public utilities from the Ministry of Finance (MoF).

5. In addition, the following actions are in the process of being taken:

- Following the government's approval of the Decentralization Project, the MoF is preparing a tax-sharing mechanism to come into effect by January 2005. Discussions are currently under way between the $\mathrm{MoF}$ and other relevant ministries regarding the extent of decentralization and the funding needs of subnational governments; these discussions will also determine the exact nature of the tax-sharing mechanism, which will be covered by a separate Act on Budgetary Rules for regional and municipal governments. It is envisaged that this mechanism will be consistent with the provisions of a major tax reform expected to come into effect in January 2004.

\section{B. Public Availability of Information}

6. Last year's ROSC concluded that the quantity, and to a large extent the quality, of information publicly available on public finances had improved substantially. At the same time, it noted that accounting, classification, and reporting of fiscal operations would benefit from the establishment of a state treasury, and recommended a number of measures, including: publishing the government's annual summary overview report, the State Budget of the Slovak Republic; providing a clear and detailed explanation of the differences between 
budget estimates and the actual outturns in the state budget document and in the state final account; reconciling outturns with ESA95 figures as notified to Eurostat; including information on the costs of providing state aid via tax measures in the budget documents; making available detailed information on the composition of state debt by instruments; developing a plan on progressive adoption of accrual accounting in line with ESA95 and the 2001 Government Finance Statistics Manual (GFSM); and reporting expenditure arrears in the state final account.

7. Last year, progress was made in these areas:

- The summary overview report The State Budget of the Slovak Republic, is published and data on the budget implementation are accessible on line on a monthly basis.

- The state final account for 2002 includes an explanation of the differences between budget estimates and actual outturns. Moreover, a quarterly report on the budget implementation (which compares budget estimates and actual outturns, and highlights risks in the budget implementation) is prepared and submitted to Parliament.

- The state final account for 2002 and the approved budget for 2003 each include a list of reconciliation items to reach the ESA95-basis fiscal balance.

- Regarding information on the tax measures provided as a form of state aid, the tax and customs section of the $\mathrm{MoF}$ annually provides this information as well as the impact on private entities. Furthermore, the State Aid Act requires reporting of such measures to the State Aid Office annually.

- $\quad$ Detailed data on the composition of state debt are published on the MoF website and information on consolidated general government debt is incorporated in the state final account.

- $\quad$ State-guaranteed loans were reported in detail in the state final account for 2002. A new law on state debt and state guarantees was approved in mid-2002. The law took full effect in January 2003, and now significantly restricts the issuance of new state guarantees.

- Progress has been made in the reporting of expenditure arrears: the liabilities of subsidized state organizations in the health sector, health insurance companies, state budget organizations, and Slovak Television and Radio were for the first time incorporated in the state final account for 2002.

8. However, some fiscal reforms have had complications for monitoring in the short run:

- Although, as noted earlier, fiscal targets are now expressed on an ESA95 basis, budgets are still presented on a cash basis, though with a list of adjustment items to reach the ESA95 fiscal balances. Thus, the breakdown of revenues and expenditures is available only on a cash basis, and on an unconsolidated basis only. The MoF is 
working actively on improving the quality of the fiscal data and, especially, on addressing weaknesses during the transition from cash to accrual recording (including the preparation of complete bridges for reconciliation).

- Significant decentralization took place in 2002, but reporting requirements for the budgets of subnational governments have not yet been accelerated.

\section{Open Budget Preparation, Execution, and Reporting}

9. The original ROSC concluded that key weaknesses in budget preparation had been largely addressed and that budget preparation was cast against a clearly identified mediumterm macroeconomic framework and constraints. However, the report noted that the transparency of budget management could be improved further by: reviewing government institutions' deposits with commercial banks; ensuring that commercial public enterprises are audited by the private sector; and adopting provisions regulating supplementary budgets and carryover of appropriation from one fiscal year to the next.

10. Consistent with these recommendations, the following steps were taken:

- The Act on the State Treasury-enacted last year-stipulates the need for a review of government institutions' deposits with commercial banks to ensure full compliance with existing regulations and to strengthen budget execution and reporting. Moreover, beginning January 2004, all public institutions that are clients of the Treasury will be required to have an account at the Treasury and will be prohibited from having deposits with commercial banks.

- The Act on Budgetary Rules was amended earlier this year to incorporate provisions regulating supplementary budgets and the carryover of appropriations from one fiscal year to the next. The MoF is allowed to submit a supplementary budget to the Parliament at the same time that it submits the quarterly reports on the budget implementation. Moreover, carryover of appropriations from one fiscal year to the next or subsequent ones is allowed only with authorization by the MoF. The new Act on Budgetary Rules-currently under preparation-is going to limit the carryover from the current fiscal year to just the next one.

\section{Independent Assurances of Integrity}

11. The original ROSC concluded that the integrity of publicly available information on public finances was ensured by clearly defined and independent scrutiny. At the same time, the staff suggested: incorporating a more rigorous sustainability analysis of the existing policy commitments as well as of the implication of new commitments; reporting on contingent liabilities, other than government guarantees; and publication of a document outlining the government's debt strategy once the Debt and Management Agency becomes operational. 
12. Work in progress includes:

- Within the ongoing Public Finance Management Reform Project several measures are under preparation, including: the introduction of a medium-term budgetary framework comprising a more rigorous sustainability analysis of the existing policy commitments as well as of the implications of new commitments; and the reporting of all contingent liabilities.

- The MoF is in the process of drafting a document outlining the government's debt strategy.

\section{IMF STAFF COMMENTARY}

13. Over the past year, Slovakia made important progress to bring fiscal transparency close to international best practice. This involved improving the coverage and availability of fiscal information; advancing work on international reporting standards; and improving the reporting of contingent liabilities and expenditure arrears. At the same time, however, some reforms - namely, the conversion of the fiscal targets and the budget from a cash to an ESA95 basis, and the decentralization process-have had complications for monitoring.

14. Looking ahead, there are a number of areas where further progress could be made in line with the original ROSC recommendations, and new legislation or amendments of existing legislation could incorporate such recommendations. Specific areas that should be addressed include:

- The clarification of financial relations with state-owned enterprises, and of the mandate of the NPF on the subject of the management of privatized enterprises.

- Including the Market Intervention Agency in central government, and the government's equity holdings in the state final account.

- Improving budget-reporting requirements for subnational governments, and ensuring that key tax sharing arrangements between the central and subnational governments are established by a transparent formula.

- Developing a plan to adopt accrual accounting progressively in line with ESA95 and the 2001 GFSM, and including a statement of accounting policy in the state budget and in the state final account.

- $\quad$ Expanding the Supreme Audit Office's mandate to perform audit of all enterprises regardless the percentage of government participation; and having commercial public enterprises also being audited by the private sector.

- Further improving the reporting of the government's contingent liabilities. 